\title{
研究速報
}

\section{カテゴリカル色知覚を考慮した色の類似度定義に関する一考 察}

\author{
Color Similarity Metric Based on Categorical Color Perception
}

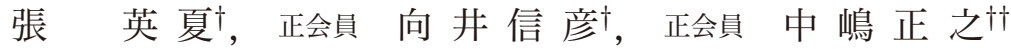

Youngha Chang $^{\dagger}$, Nobuhiko Mukai ${ }^{\dagger}$ and Masayuki Nakajima ${ }^{\dagger \dagger}$

\begin{abstract}
The calculation of color difference is one of the most basic techniques in image processing fields. For example, color clustering and edge detection are the first steps of most image processes and we compute them by using a color difference formula. Although the CIELAB color difference formula is a commonly used one, the results obtained with it are not in accordance with human feelings when the color difference becomes large. In this paper, we have performed psychophysical experiments on color similarity between colors that have large color differences. We have then analyzed the results and found that the similarity is strongly restricted by the basic color categories. In accordance with this result, we propose a new color similarity metric based on the CIEDE2000 color difference formula and categorical color perception.
\end{abstract}

キーワード : 色知覚，色差，色の類似度，心理視覚実験，基本色カテゴリー，カテゴリカル色知覚

\section{1. ま え がき}

DTP (DeskTop Publishing) や製品製造ラインなど，さ まざまな分野において色差検査が取り入れられている。こ れら多くの分野で取り入れられている色差は「色の分別」 に言い換えることができる。一方，画像処理分野ではエッ ジ検出や領域クラスタリングなどのように比較的大きな色 差を抽出するために色差式を利用しており, この場合, 色 差は「色の分別」ではなく,「色の類似度」と言い換えるこ とができる．色差の定義は古くから CIE(Commission Internationale de l'Eclairage) を主導に標準化作業が進めら れており，代表的なものに CIELAB 色差式がある ${ }^{1)}$.こ れは色空間における距離が色差に対応するように作られた 均等色空間である. CIELAB の色差式は広く普及している が，色差の許容值が明度やクロマに依存することなどが報

2012 年 3 月, 電子情報通信学会パターン認識・メディア理解/ヒューマン情 報処理研究会にて発表

2012 年 7 月 20 日受付, 2012 年 10 月 10 日再受付, 2013 年 1 月 25 日 採録

†東京都市大学 知識工学部

（广 158-8557 世田谷区玉堤 1-28-1, TEL 03-5707-0104)

††ゴットランド大学

(スウェーデンビスビュー)

$\dagger$ Knowledge Engineering, Tokyo City University

(1-28-1 Tamazutsumi, Setagaya-ku, Tokyo 158-8557, Japan)

$\dagger \dagger$ School for Game Design, Technology and Learning Processes, Gotland University

(Cramergatan 3, 62157, Visby, Sweden)
告され ${ }^{2)}$, 非等色差性を補正するための色差式が提案され た ${ }^{3)}$. . 一方で, 比較的大きな色差に関する心理視覚実験も 存在し ${ }^{5) 6)}$, 色空間の歪みが確認されている。しかしなが ら，この歪みが既知の色分別能に由来する歪みなのか， あ るいは別の原因によるものなのかは明らかにされていない. そこで本稿では, 色の差が大きい色同士の類似度実験を行 うことにより, CIELAB 色空間の歪みとその歪み方の特徴 について分析を行い，その結果に基づいて色差を修正する 手法について検討する.

\section{2. 実 験 の 概 要}

色の類似度は絶対的な尺度ではなく，比較対象があって 初めて成立する相対的な尺度である。したがって，本実験で は色 A と色 B が類似しているか否かを調べるために，もう 一つの色 $\mathrm{C}$ を提示し， 3 色間での相対的な比較を行う。本 稿では，A を基準色， $\mathrm{B}$ を比較色， $\mathrm{C}$ を参照色と記す。基 準色と参照色を固定し, 複数の色を比較色として実験を行 う。もし, CIELAB 色空間上の距離が色差と等しいのであ れば，基準色に対して参照色より近い比較色はより類似し ており，遠い色は類似していないはずである。また，基準 色を中心とし, 基準色から参照色までの距離を半径とする 円上の色は参照色と同等の類似度を持ってはずである。そ こで実験結果を $a * b *$ 平面上に描き, 類似度の分布形状を調 べることで，色空間の歪みと歪みの傾向を分析する。 


\section{1 実験の手順}

実験は D65 光源の下で校正された sRGB モニタを用い て行う。被験者はモニ夕から $50 \mathrm{~cm}$ 離れたところに座り，画 面上に現れる基準色が参照色と比較色のどちらに似ている のかを応答する。

\section{2 実験画面の構成}

図 1 に実験画面例を示す。三つの色刺激は視野角 $2^{\circ}$ の 円で表示する。各色刺激の間隔は視野角 $3^{\circ}$ とし，実験の 背景色は $\mathrm{L}^{*}=50$ の灰色となるように設定する。基準色は 画面中央に, 参照色および比較色は基準色の左右どちらか に描画される。三つの色を同時に提示することにより, 色 の対比現象が発生する可能性があるが, キルシュマンの第 二法則 7)によると色刺激間の距離が大きくなるほど対比現 象は発生しなくなるとある。また, 近藤らの研究 ${ }^{8)}$ による と色刺激間の距離が視野角 $1^{\circ}$ 以上離れていれば色対比現 象はほとんど起こらないとされている。このため本研究で は，3色を同一画面上に提示する際に対比現象は発生しな いと仮定する.

\section{3 実験データ}

CIELAB 色空間の明度 $\mathrm{L}^{*}=50$ の $\mathrm{a} * \mathrm{~b} *$ 平面において実 験に用いる色データをサンプリングする。まず，図 $2(a)$ に 示すように, 原点を中心とした半径 20 の円上に $45^{\circ}$ 間隔で 8 点サンプリングし, 基準色とする. 次に, 図 2(b) に示す ように，各基準点を中心に放射状に色度点をサンプリング する。 まず基準色から 8 方向に放射線 $L_{i},(i=1, \ldots, 8)$ を 描き，放射線上に色差 5 の間隔で 6 色をサンプリングする. 基準色から $\mathrm{a}$ *軸に平行かつ正方向に延びた放射線 $L_{1}$ 上の 色度点を参照色とする．他の放射線上の色は比較点とする. つまり, 基準色 8 点, 参照色 6 点, 比較色 42 点 $(6$ 点 $\times 7$ 方向) の組合せで実験を行う。しかしながら，全組合せを実 験するには膨大な時間を要するため, 数の減少を図る。 二 つの色度点 $C_{1}$ と $C_{2}$ の $\mathrm{a}^{*} \mathrm{~b}$ *平面上の距離を $d\left(C_{1}, C_{2}\right)$ と する。 ここで基準色 $A$ に対し, 参照色 $B$ は放射線 $L_{1}$ 上, 比較色 $C$ は放射線 $L_{i},(i \neq 1)$ 上にある。もし， $A$ と $B$ の 類似度が $A$ と $C$ の類似度よりも高いと応答されたとすれ ば, $d(A, B)>d\left(A, B^{\prime}\right)$ を満たし $L_{1}$ 上にある参照色 $B^{\prime}$ については, $A$ と $B^{\prime}$ の類似度が $A$ と $C$ の類似度よりも高 いと見なし, 実験を行わない. 同様に, 比較色 $C^{\prime}$ が $C$ と 同じ放射線 $L_{i}$ 上にあり $d(A, C)<d\left(A, C^{\prime}\right)$ の場合, $A$ と $C^{\prime}$ の類似度が $A$ と $B$ の類似度よりも低いと見なし, 実験 は行わない.このようにすることで, 被験者の応答に応じ た組合せ数の動的な減少が可能となる.

\section{3. 実 験 結 果}

30 代の女性 2 名に対し，2 回ずつ実験を行つた。実験結 果例を図 3(a) に示す。基準色 $A$ は黒の四角 $(\boldsymbol{\square})$, 参照色 $B$ は緑の三角 $(\boldsymbol{\Delta})$ で示した。比較色 $C$ は, $A$ と $C$ の類 似度が $A$ と $B$ の類似度よりも高い場合にはマジェンタの 円 $(\boldsymbol{O})$, 低い場合には青の菱形 $(\diamond)$ で示した。もし, 色空
間上の距離が人間の色差感覚に対応していれば，マジェン 夕の円は，黒四角を中心とした真円状に並ぶはずであるが， 基準色より $\mathrm{b}$ *值が大きい方に偏っていることがわかる.

次に，この歪みをマンセル表色系の $\mathrm{a}^{*} \mathrm{~b}$ *平面上での歪 みと比較した。そのために, 文献 9) の附属書付表 1 を用 いて，マンセル表色系の等色相線および等彩度線を算出し， これらを実験結果に重畳表示した(図 3 左から 2 番目の 列). 図 $3(\mathrm{~b})$ では，等色相線および等彩度線を勘案すると， 基準色と参照色の色相および彩度の差異が小さいことがわ かる。しかしながら，被験者によって参照色より類似して いるとされた比較色 (マジェンタの円) は，色相および彩度 において広範囲に渡って分布しており，マンセル表色系に おける色差と被験者による応答が一致しないことがわかつ た。図 3(e) に別の例を挙げる。この場合，より類似してい

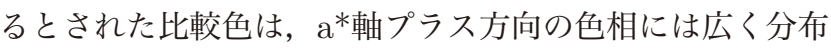
しているが， $a^{*}$ 軸マイナスの方向にはそれほど分布してお らず，等色相線の方向とは一致しない広がりを見せている. このように，実験結果からは色空間における一定方向への 歪み，例えば，色相や彩度に依存した歪みや，マンセル表 色系を $a^{*} b$ *平面に再現した際の歪みなどでは説明できない 歪みが確認できた.

実験の結果として得られた類似度分布の歪みを，人間の 高次色視覚処理特性である基本色カテゴリー (BCC: Basic Color Categories) ${ }^{10)}$ に関連づけて分析した。 図 3(c),(f),(i) は， $\mathrm{a}^{*} \mathrm{~b}$ *平面を基本色カテゴリーに分割 ${ }^{11)} し た$ 結果に実 験結果を重畳表示したものである。 $\mathrm{a}^{*} \mathrm{~b}$ *平面の色分布が基 本色カテゴリーを示す。図 3(i) では，実験に用いられた基 準色は “緑” と知覚される色力テゴリーに属し, 参照色が “緑” “茶” の中間色であったため, “緑” と知覚される比 較色は基準色に似ているが, “灰色”や“茶”という別の力 テゴリーに属す比較色は類似していないという結果になっ た. 同様に，(c) や (f)でもカテゴリー内の色はより似てい ると応答されており, カテゴリーが異なる色については似 ていないと応答されていることがわかった。

この結果について, 我々は以下のように解釈した。色知 覚は, 連続的な色空間の中で色の差異を弁別する連続的知 覚と，色をカテゴリーに分類し，あたかも離散的な量であ るような扱いをする離散的知覚という，二重構造になって いる ${ }^{12) 13)}$. したがって, 人間が知覚できる色差 (マンセル 表色系から解釈できる色差) に対し，カテゴリカル色知覚 の境界効果 ${ }^{14)}$ が加わり，カテゴリーが異なる 2 色間の色 差はより大きく, カテゴリー内部の色差はより小さく知覚 されたと解釈した。

\section{4. 類似度の尺度}

3 の分析結果を基に，本稿では基本色カテゴリーを取り 入れた色差式を以下のように定義する.

$$
\Delta E_{\text {new }}\left(l a b_{0}, l a b_{1}\right)=w\left(l a b_{0}, l a b_{1}\right) \Delta E_{00}\left(l a b_{0}, l a b_{1}\right)(1)
$$


ここで, $l a b_{0}, l a b_{1}$ は色の CIELAB 值, $\Delta E_{00}$ は CIEDE2000 色差式である. CIEDE2000 とは, CIELAB 色空間上における知覚的誤差を改善するために策定された 色差式である ${ }^{15)}$. 本稿では, この CIEDE2000 にカテゴ リカル色知覚のカテゴリー境界条件を加えることによって, 新たな色差式を提案する. なお, $w\left(l a b_{0}, l a b_{1}\right)$ は基本色力 テゴリによる色差制御のための重み関数であり, 式 $(2)$ の 通り定義する。

$$
\begin{aligned}
w(a, b) & =F((\overrightarrow{p(a)} \cdot \overrightarrow{p(b)}) /(|\overrightarrow{p(a)}||\overrightarrow{p(b)}|)) \\
F(x) & =t(1-\varsigma(2 x-1))+1,(t>1)
\end{aligned}
$$

ここで, ऽはシグモイド関数である. $\overrightarrow{p(c)}$ は 11 次元の ベクトルであり, 各成分 $p_{i}(c),(i=0, . ., 10)$ は色 $\mathrm{c}$ が各基 本色カテゴリーに属する確率を表す。例えば, $p_{0}(c)$ は色 $\mathrm{c}$ が赤カテゴリーに属する確率, $p_{1}(c)$ は青カテゴリーに属す る確率を示す。なお, $\sum_{i=0}^{10} p_{i}(c)=1$ である。確率 $p_{i}(c)$ は 従来研究 ${ }^{11)}$ の結果に基づいて計算できる. また, 式 (2) の 定数 $t$ は実験結果から最小二乗法により, 3.7321 と求めた.

本提案式の妥当性を調べるために, 被験者 1 の 1 回目の 結果を正解とし, 提案色差式と CIEDE2000を比較する. まず，基準色と比較色の色差および，基準色と参照色の色 差を求める. 次に, 両色差の值から, 比較色と参照色のど ちらが基準色に類似しているのかを調べ, 結果を被験者 1 の 1 回目の結果と比較する. 結果として,

- 両色差とも実験結果と一致:1460 個

- $\Delta E_{00}$ 正解, $\Delta E_{n e w}$ 不正解:36 個

- $\Delta E_{00}$ 不正解, $\Delta E_{\text {new }}$ 正解:103 個

- 両方とも実験結果と不一致:237 個

となった. 被験者 2 との比較でも同様の結果が得られた. 以上から, 本提案式の方が実験結果に近いことが分かった. 次に, 実験データ以外の色について, 提案色差式 $E_{n e w}$ と CIEDE2000 の色差式 $E_{00}$ を用いて色の類似度を求めた. そのために, 色空間全体について任意の三つの色 $c_{1}, c_{2}, c_{3}$ をサンプリングし， $c_{1}$ と $c_{2}, c_{1}$ と $c_{3}$ それぞれの色差を計 算することで, $c_{1}$ が $c_{2}$ と $c_{3}$ どちらに類似しているかを求 めた。 その結果例を図 4 に示す. 図 4 には, 色差計算の結 果が CIEDE2000 と提案色差式で異なった場合の結果例の みを示す。図 4 の中央の列が $c_{1}$, 左が本提案色差式で類似 していると計算された色，右が CIEDE2000で類似してい ると計算された色である. 図 4 からわかるように, 本提案 色差式の方が人間の知覚に近いことがわかる.

\section{5.むすび}

本稿では, 人間が類似していると知覚する色の色空間内 における分布を実験によって求めた。 その結果, 知覚的歪 みが確認され, この歪みには基本色カテゴリーが大きく影 響していることが分かった。このため, 基本色カテゴリー
の影響を考慮した新たな色の類似度計算式を提案し，その 有効性を示した。

今後は色データと被験者数を増やし, 色空間全体に対す る実験を行い, 妥当性についてさらなる検証を行う予定で ある。 また, カテゴリー境界効果について検証を行つていく 予定である.さらに, 色差式の妥当性評価および画像処理の 応用における効果についても検証を行う予定である。

\section{(文献)}

1) Alan R. Robertson: "Historical Development of CIE Recommended Color Difference Equations", Color Research and Application, 15, 3, pp.167-170 (1990)

2) Roderick McDonald: “Industrial pass/fail colour matching part III", Journal of the Society of Dyers and Colourists, 96, 9, pp.486-497 (1980)

3) CIE : Industrial Colour-Difference Evaluation, CIE Technical Report, 116-1995 (1995)

4) Gaurav Sharma, Wencheng Wu, Edul N. Dalal: “The CIEDE2000 Color-Difference Formula: Implementation Notes, Supplementary Test Data, and Mathematical Observations", Color Research and Application, 30, 1, pp.21-30 (2005)

5) DH Kim, EK Cho, JP Kim: “Evaluation of CIELAB-based Colour-Difference Formulae Using a New Dataset", Color Research and Application, 26, 5, pp.369-375 (2001)

6) Haisong $\mathrm{Xu}$, Hirohisa Yaguchi, Satoshi Shioiri: “Testing CIELAB-based Color-Difference Formulae Using Large Color Differences", Optical Review, 8, 6, pp.487-494 (2001)

7) August Kirschmann: "Ueber die quantitativen Verhaltnisse des stimultanen Helligkeits und Farben-Contrastes", Philosophische Studien, 6, pp.417-491 (1891)

8) Aki Kondo, Hiroki Yamamoto: "Effects of luminance contrast on chromatic induction", Perception, 37, p.147 (2008)

9）JIS Z8721："色の表示方法-三属性による表示” (2005)

10) Brent Berlin, Paul Kay: "Basic Color Terms: Their Universality and Evolution”, Cambridge University Press (1969)

11) Youngha Chang, Suguru Saito, Keiji Uchikawa, Masayuki Nakajima: "Example-based Color Stylization of Images”, ACM Transaction on Applied Perception, pp.322-345 (2005)

12）内川惠二: “色覚のメカニズム”, 第 9 章, 朝倉書店 (1998)

13）内川惠二: “表面色のカテゴリカル知覚”, 光学, 17, 12, pp.661-669 (1988)

14) S.Harnad: “Psychophysical and cognitive aspects of categorical perception: A critical overview”, chap.1, Cambridge University Press (1987)

15) M.R.Luo, G.Cui, B.Rigg : “ The development of the CIE 2000 colour-difference formula: CIEDE2000”, Color Research and Application, 26, 5, pp.340-350 (2001)

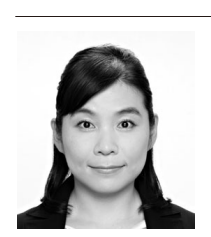

椳 㒭夏 1998 年, 韓国梨花女子大学卒業. 2004 年, 東京工業大学大学院情報理工学研究科博士後期 課程修了。同年，同大研究員. 2006 年，同大大学院情報 理工学研究科助手. 2007 年, 同大大学院情報理工学研究 科助教. 2012 年, 東京都市大学知識工学部講師. 現在に 至る. コンピュータグラフィクス, 画像処理の研究に従 事. Ph.D.

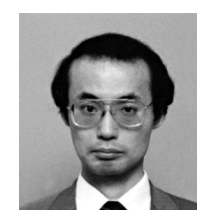

势年 信彦 1983 年, 大阪大学基礎工機械卒業。 1985 年, 同大大学院博士前期課程修了. 同年, 三菱電機 (株) 入社. 1997 年, コーネル大コンピュータサイエン 修士課程修了。2001 年, 大阪大学大学院博士後期課 程修了. 博士 (工学)。2002 年, 武蔵工業大学 (現東京都 市大学) 工学部電子情報工学科助教授. 2007 年, 同大知 識工学部情報科学科教授. 画像工学に関する研究に従事. 正会員.

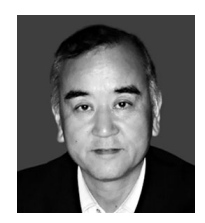

なが゙ま鳥 正之 1969 年, 東京工業大学工学部電気工 学科卒業。1975 年, 同大大学院博士課程修了. 同年, 同 大勤務. 1983 年, 同大像情報工学研究施設助教授. 1992 年, 同大電気電子工学専攻教授. 1994 年, 同大大学院 情報理工学研究科教授. 2012 年, 神奈川工科大学客員 教授, スウェーデンゴットランド大学教授, 現在に至る. コンピュータグラフィクス, コンピュータアニメーショ ン, 画像処理の研究に従事. 工博. 正会員. 


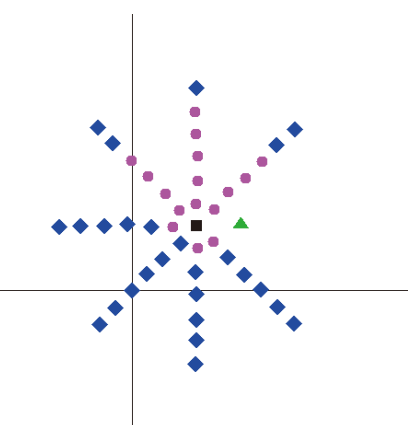

(a) 実験結果 1

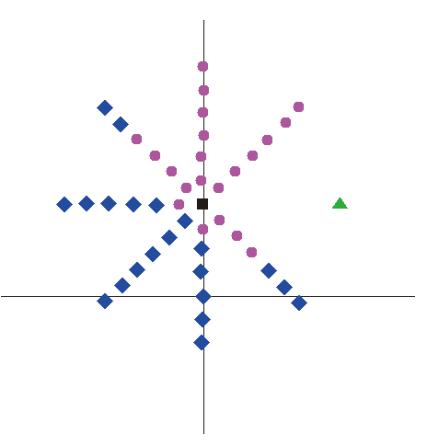

(d) 実験結果 2

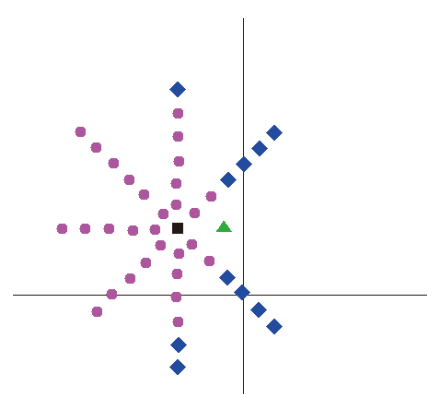

(g) 実験結果 3

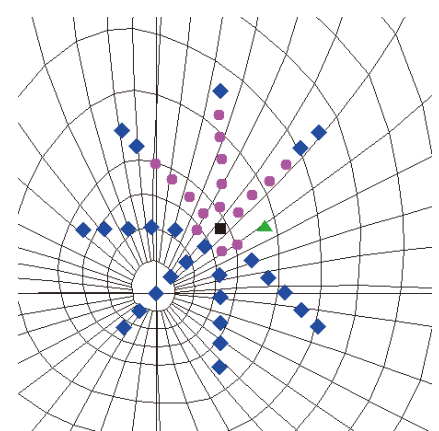

(b) (a) とマンセルの重畳表現

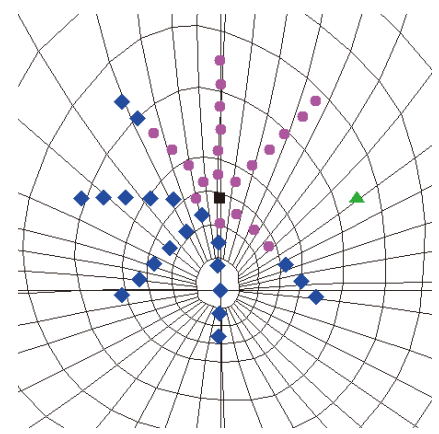

(e) (d) とマンセルの重畳表現

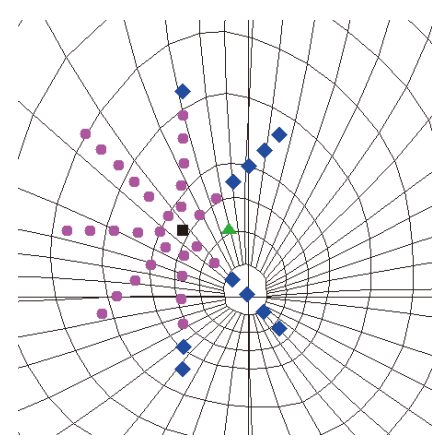

(h) (g) とマンセルの重冨表現

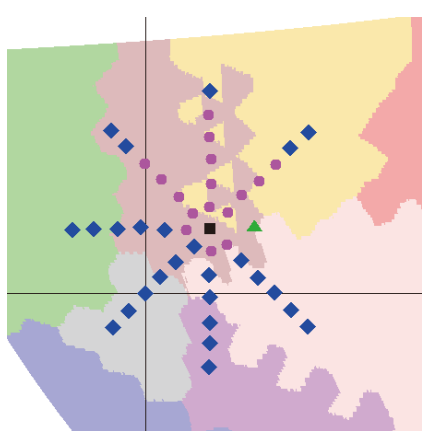

(c) 基本色カテゴリーの重畳表現

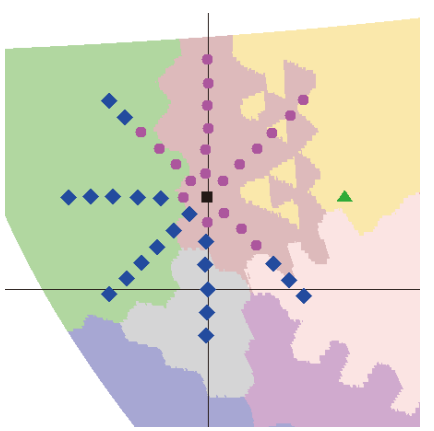

(f) (d) と基本色カテゴリーの重畳表現

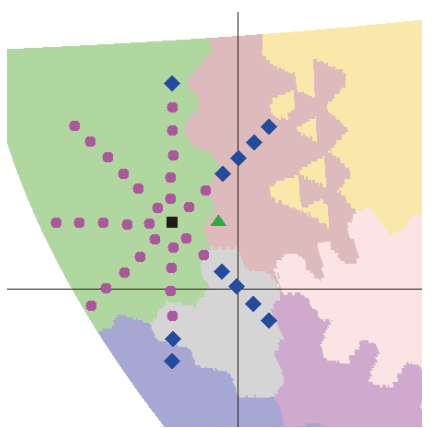

（i）（g）と基本色カテゴリーの重畳表現

図 3 色の類似度の心理視覚実験結果例

Results of psychophysical experiment.

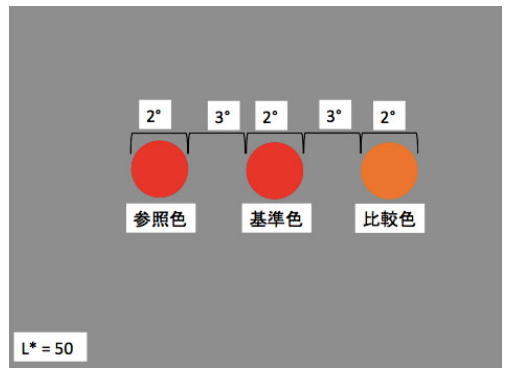

図 1 実験画面構成 Stimuli layout.
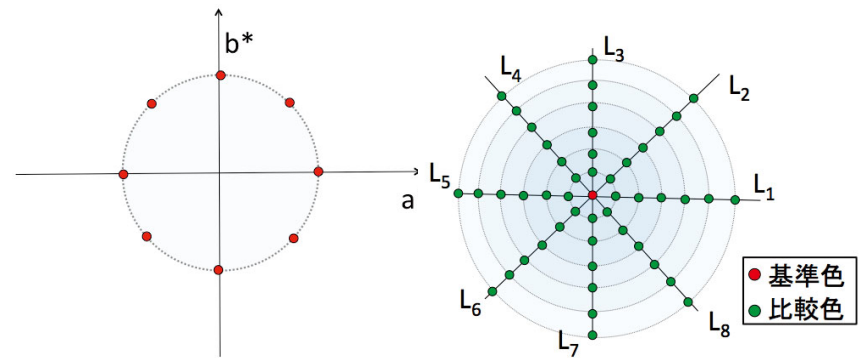

(a) 基準色のサンプリング

(b) 参照色と比較色のサンプリング

図 2 実験色刺激のサンプリング

Sampling of experimental data.

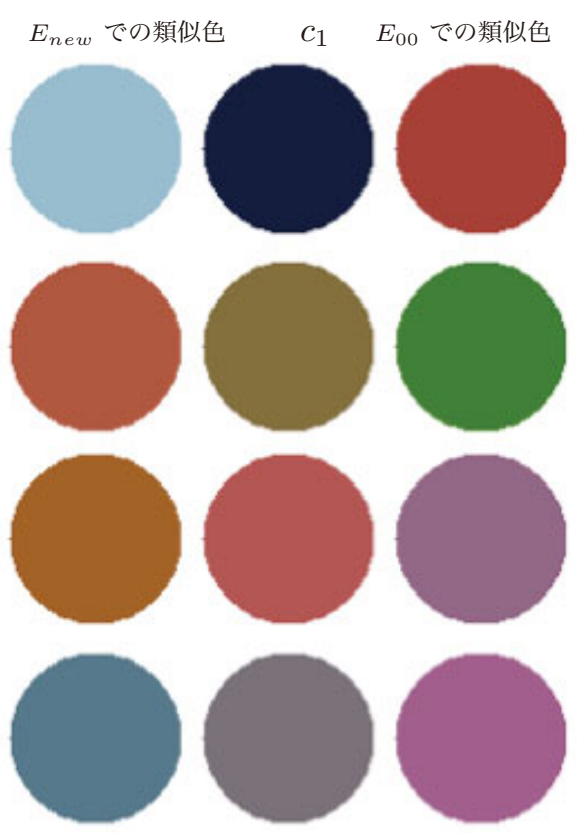

図 4 色差計算の結果. 本提案式と CIEDE2000 との比較 Results of color difference calculation. 